Dossiê - Para além do “ativismo judicial” e da “judicialização da política” DOI: $10.5433 / 2176-6665.2016 \mathrm{v} 21 \mathrm{~N} 1 \mathrm{P} 199$

\title{
Supremo ESPETÁCUlo: APROXIMAÇões SOBRE AS IMAgENS PÚBLICAS DO STF
}

\author{
Fernanda Da Silva Borges ${ }^{1}$ \\ SANDRo BALlande Romanelli ${ }^{2}$
}

\begin{abstract}
Resumo
O presente trabalho insere-se nos debates contemporâneos entre Judiciário, Política, Democracia e Mídia. A utilização de expressões como ativismo jurídico, protagonismo judiciário e governo de juízes nos aponta, em certa medida, algumas das transformações ocorridas nas democracias contemporâneas. A articulação entre a função judicial e o sistema político, mais especificamente a dimensão política da atuação das cortes judiciais tem despertado interesse crescente entre cientistas políticos, juristas e sociólogos. Nosso desafio é problematizar os riscos à democracia provocados pela ampliação do poder judicial e o empoderamento dos juízes, levando em consideração o lugar de visibilidade e espetacularização do Judiciário.
\end{abstract}

Palavras-chave: Democracia. Judiciário. STF. Mídia.

\section{SUPREME SPECTACLE: AN APPROACH ON STF'S PUBLIC IMAGES}

\begin{abstract}
This article seeks to contribute to the actual debate around the Judiciary, Politics and Media. Expressions such as judicial activism, judicial protagonism and government of judges demonstrate, in certain extent, some of the changes occurred in contemporary democracies. Interactions between judicial functions and the political system - more specifically the political dimension of court rulings - has

1 Doutoranda em Sociologia na Universidade Federal de Goiás (UFG), com pesquisa financiada pela Capes, e Professora-Assistente de Direito da Pontifícia Universidade Católica de Goiás (PUC-GO), Brasil. fsilvaborges@hotmail.com

2 Doutorando em Direitos Humanos e Democracia na Universidade Federal do Paraná (UFPR) e Professor do Instituto Federal do Paraná (IFPR), Brasil. sromanelli@gmail.com
\end{abstract}


awakened renewed interests among political scientists, legal scholars and sociology researchers. Our challenge is to accurately describe the visibility and media around the Judiciary branch, taking into account which risks to democracy can arise from the broadening of judicial power and the growing power of judges.

Keywords: Democracy. Judiciary. Brazilian supreme court. Media.

\section{CONSIDERAÇÕes INICIAIS ${ }^{3}$}

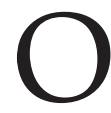

termo spetaculum, raiz semântica de espetáculo, tem como significado tudo que atraí e prende o olhar e a atenção. A expressão "sociedade do espetáculo", cunhada pelo escritor francês Guy Debord", deu margem a variadas e distintas interpretações. Debord define o espetáculo como o conjunto das relações sociais mediadas pelas imagens, ou seja, “o espetáculo não é um conjunto de imagens, mas uma relação social entre as pessoas, mediatizadas por imagens." (DEBORD, 2003, p. 14). De acordo com o autor não é possível separar as relações sociais das relações de produção e consumo de mercadorias, visto que a sociedade do espetáculo corresponde a uma fase da sociedade capitalista, quando há uma interdependência entre o processo de acúmulo de capital e o processo de acúmulo de imagens. Em outras palavras, o estágio espetacular da sociedade é o momento em que o processo de acumulação capitalista avança sobre a vida cotidiana com fins de organizá-la para o consumo.

Em Comentários sobre a Sociedade do Espetáculo, publicado em 1988, Debord afirma que a produção de espetáculos, ao invés de ter sido enfraquecida ou mesmo destruída, se fortaleceu e tomou conta de toda a vida. Será que a noção de espetáculo, ligada a uma postura crítica em relação à sociedade capitalista, pode nos ajudar a compreender as sociedades contemporâneas?

3 Agradecemos aos editores e pareceristas anônimos da Revista Mediações pelas contribuições à melhoria do artigo e do escopo da pesquisa proposta.

4 Considerado um autor bastante controverso, Debord publicou sua obra $A$ Sociedade do Espetáculo, em 1967, em forma de teses (221) sobre o espetáculo. 
Para Rubim (2002), os espetáculos do contemporâneo são produzidos em conjunto com a mídia e outros atores sociais. Dessa forma, não deveríamos acolher integralmente as elaborações teóricas formuladas por Debord, sem nos atentarmos aos limites e flutuações conceituais presentes na própria obra. Segundo Rubim (2002), Debord atribui ao espetáculo um viés naturalmente negativo. Tal visão diz respeito à perspectiva intrinsecamente mercantil e capitalista do espetáculo, que elimina a existência de contradições em seu processo de produção. É como se o espetáculo estivesse aprisionado ao capital, não sendo produzido fora de seus limites ou de forma antagônica. Nesse sentido, a visão debordiana não se configuraria como a única para uma elucidação crítica, atual e satisfatória do espetáculo nas sociedades contemporâneas.

Logo, podemos revisitar a noção de sociedade do espetáculo, apontando suas limitações e desenvolvendo algumas de suas premissas. Conforme nos aponta Requena (1998, p. 92), "o preço da onipresença, da cotidianização do espetáculo é sua dessacralização." Em outras palavras, em um mundo em que tudo pode e tende a ser transformado em espetacular, nada mais parece ser espetacular.

[...] em uma sociedade do espetáculo, em que tudo tende ao espetacular, a espetacularização, paradoxalmente, também encontra obstáculos para deslanchar e operar. Pode-se então redefinir os termos da formulação da contemporaneidade como "sociedade do espetáculo". Ela está em sintonia com a fase atual do capitalismo, na qual a informação e a comunicação tornam-se mercadorias privilegiadas e a economia do espetáculo aparece como cada vez mais relevante. Mas ela também pode ser caracterizada como a sociedade em que, diferente do que acontecia nas anteriores, quando o espetacular era algo da esfera do extraordinário e da efemeridade, agora o espetáculo potencialmente está (oni)presente, no espaço e no tempo, e afeta radicalmente toda a vida societária (RUBIM, 2002, p. 19). 
Na esteira do trabalho de Debord, a obra de Roger-Gérard Schwartzenberg, O Estado Espetáculo (publicada em 1977), propõe uma discussão sobre política e poder político no âmbito do espetáculo. Para Schwartzenberg (1978, p.3), o Estado se transforma em teatro de ilusões, em "produtor" de espetáculos de forma sistemática e organizada: "a política era ideias, hoje é (sic) pessoas, personagens, pois cada dirigente parece desempenhar um papel. Como num espetáculo". O "mito do herói" exprime a teatralidade política com mais intensidade, pois esta personagem produz uma autoridade mais "espetacular", tendo assim um amplo poder de mobilização. "O herói é, portanto, um homem do espetáculo." (SCHWARTZENBERG, 1978, p. 14).

Nosso desafio é utilizar a noção de espetáculo pela lógica produtiva da mídia, relacionada à ideia de representação pública e atores sociais judiciais, ora se aproximando, ora se afastando do conceito debordiano. Além disso, buscamos problematizar os riscos que a ampliação do poder judicial e o empoderamento dos juízes podem provocar à democracia, levando-se em consideração as tensões e contradições do discurso midiático em relação ao STF.

O tema central deste artigo é a construção da imagem do supremo por si e pelos outros, buscando inserir novos elementos no debate sobre o ativismo judicial e da judicialização, a permitir outro ponto de observação sobre o poder judiciário e sua relação com a sociedade democrática. Assim, diante da possibilidade de uma abordagem teórico-metodológica interdisciplinar (para além das perspectivas mais convencionais), propomos um diálogo entre as Ciências Sociais, o Direito e a Análise do Discurso.

O texto apresenta a questão da expansão do poder judicial e a relação conflituosa entre o judiciário e os meios de comunicação, mais especificamente a partir de dois pontos de vista: $a$ ) a construção midiática da imagem do STF e seus ministros e b) as informações que o próprio Supremo veicula por meio de seus canais de comunicação, 
em especial por meio do portal institucional www.stf.jus.br. O artigo limita-se ao exercício metodológico de uma singela comparação entre informações veiculadas sobre o Supremo e aquelas veiculadas pelo Supremo Tribunal Federal, tecendo, a partir da tensão entre o coletivo (a Corte) e o individual (os Ministros), uma trama com a pretensão de reconstituir uma possível imagem pública do STF que indica, em análise preliminar, a espetacularização de sua imagem.

\section{Protagonismo e Visibilidade: O SUPRemo SOB OS HOlOFOtes}

No palco da democracia contemporânea ter visibilidade torna-se fundamental. A constante presença (ou aparição) nos meios de comunicação, ainda que sob um caráter teatral, permite produzir a "impressão de transparência", isto é, sugere uma exposição pública de prestação de contas que parece essencial à democracia. Nesse sentido, os atores sociais, em interação e disputa por poder no espaço políticodecisório, são obrigados a (re)elaborar e (re)significar suas estratégias comunicativas, modificando os discursos conforme os recursos disponíveis e os interesses buscados. Tal processo de "adequação" a dinâmica midiática se relaciona a alterações da linguagem e de novos modos de comunicação.

As mudanças sociais, econômicas e políticas, ocorridas ao longo da segunda metade do século $\mathrm{XX}$, contribuíram para o deslocamento dos tribunais para o centro do debate público. Os juízes, especialmente em sociedades democráticas e plurais, assumiram um papel de destaque, estando cada vez mais expostos e ajustando-se a diferentes scripts. Deste modo,

[...] poucos personagens sofreram tantas modificações nos últimos anos quanto os magistrados. Sua presença transpôs as portas dos fóruns. Dificilmente se encontrará um tema ou um embate sobre o qual não se solicite a palavra ou não se pronuncie um magistrado. Como protagonistas centrais, juízes, desembargadores e ministros de tribunais 
têm ocupado espaços na arena pública, marcando posição e desempenhando papeis que extrapolam a clássica imagem de discrição ou de extrema impessoalidade (SADEK, 2006, p. 11).

A Constituição de 1988 conferiu ao STF uma arquitetura institucional e funcional sui generis. As decisões judiciais de grande repercussão política e social têm ocupado as primeiras páginas de jornal, revistas, noticiários televisivos e redes sociais. Os juízes têm sido questionados acerca de suas decisões pelos mais variados meios de comunicação. Será que estamos vivendo o momento de maior visibilidade do poder judicial?

O livro de Aliomar Baleeiro, O Supremo Tribunal Federal, esse outro desconhecido, escrito no final da década de 1960, nos faz pensar o lugar institucional e simbólico ocupado pelo STF no Brasil nos últimos anos. $\mathrm{O}$ autor expõe de que forma, ainda aos 13 anos, descobre a existência da Corte e as circunstâncias políticas deste fato. ${ }^{5}$ Com o sugestivo título, Baleeiro apresenta à sociedade um Órgão que mantinha certa discrição e exercia um papel coadjuvante no cenário político nacional. No entanto, esse papel de coadjuvante ficou para trás, posto que as mudanças advindas do pós-1988 em relação ao Poder Judiciário são bastante significativas e transformadoras. De certa forma, uma das características das democracias constitucionais contemporâneas é ter um Judiciário mais atuante, que funcione como efetivo garantidor dos direitos fundamentais e das regras do jogo político estabelecidas pela Constituição.

Porém, o que nos instiga são as contradições que a ampliação do poder judicial e o empoderamento dos juízes podem provocar.

5 O Supremo Tribunal Federal aparece pela primeira vez para Baleeiro no episódio das eleições presidenciais de 1919, disputadas por Rui Barbosa e Epitácio Pessoa. Foi através de um Habeas Corpus concedido pelo STF a Rui Barbosa (garantindo a liberdade de expressão e a circulação de seus partidários políticos). Como muitos familiares de Aliomar apoiavam a candidatura de Rui Barbosa, ele conta que acordou com a família festejando a concessão do HC e como este episódio marcou sua vida. 
Nesse sentido, transcreve-se a síntese elaborada por Andrei Koerner (2013, p. 72) da percepção corrente ${ }^{6}$ sobre o ativismo:

$\mathrm{O}$ ativismo judicial indica uma situação-limite, as fronteiras fluidas, mas necessárias, entre dois mundos distintos, o da política e o do direito. Ao ultrapassar essas fronteiras e ingressar num domínio que não lhe é próprio, o agente judicial - o juiz, um tribunal ou o Judiciário como um todo - produziria riscos, extrapolaria suas funções, distanciar-se-ia de seus quadros de referência e atuaria sob o efeito de influências indesejáveis, como valores subjetivos, preferências, interesses, programas políticos.

Os conflitos vividos entre a esfera política e a esfera jurídica estão quase sempre atravessados pelos discursos da mídia, provocando assim, diferentes desdobramentos em relação à imagem e percepção do Judiciário, especialmente do STF e de seus ministros. De tal modo, à medida que o tribunal passa a decidir cada vez mais sobre questões relevantes do cotidiano dos cidadãos, maior exposição e visibilidade este ator alcança nos meios de comunicação.

A ideia do Judiciário como o último reduto político-moral da sociedade é uma situação preocupante e complexa, que pode ocasionar efeitos desastrosos para as práticas democráticas. É possível relacionar o que Ingeborg Maus (2002) chamou de "superego da sociedade órfã" à realidade brasileira, sobretudo, em relação à expansão do papel de atores judiciais e da crescente normatização da vida social. A socióloga alemã aponta os excessos na evidenciação da pessoa do magistrado, levado à condição de celebridade, figura exemplar, espelho moral da

6 Síntese das obras de Elival Ramos ("Ativismo judicial, parâmetros dogmáticos". São Paulo: Saraiva, 2010), Luís Roberto Barroso ("Judicialização, ativismo judicial e legitimidade democrática". Revista EMARF, Cadernos Temáticos: Seminário Nacional sobre Justiça Constitucional, dez. 2010, p. 389-406) e Mayra M. Miarelli e Rogério M. Lima (“Ativismo judicial e a efetivação de direitos no Supremo Tribunal Federal". Porto Alegre: Sergio Antonio Fabris, 2012).

7 Mesmo sabendo que Maus (2002) publicou, “O Judiciário como superego da sociedade: o papel da atividade jurisprudencial na 'sociedade órfã", no contexto da Corte Constitucional Alemã, é possível fazer uma relação com a realidade do STF no Brasil. 
sociedade. É como se os juízes atuassem como deuses do direito e, consequentemente, o judiciário escapasse de qualquer mecanismo de controle social.

No Brasil vivemos uma situação próxima ao cenário descrito por Maus, na medida em que boa parte da população já reconhece os Ministros do STF e pode acompanhar pela TV os julgamentos desta corte. Nesse sentido, algumas questões podem ser suscitadas: Que tipo de relação os meios de comunicação e a opinião pública estabelecem (ou deveriam estabelecer) com o Poder Judiciário? Quais as condições de emergência dos discursos sobre e pelo o STF? Que efeitos de sentido os enunciados em relação ao STF produzem?

\section{O Supremo Tribunal Federal e o Discurso Midiático}

Em entrevista ao jornal Folha de São Paulo, a respeito da Ação Penal 470, mais conhecida como mensalão, o constitucionalista português José Joaquim Gomes Canotilho afirmou que o STF é um dos tribunais mais poderosos do mundo, com atribuições bem mais amplas que a Suprema Corte dos Estados Unidos, e também "muito mais poderoso" que qualquer tribunal europeu (MENDONÇA, 2013).

Em que pese os avanços consagrados pela Constituição de 1988, historicamente houve um considerável afastamento (muitas vezes proposital) do Judiciário em relação aos meios de comunicação. Este isolamento dos juízes e a dificuldade em dialogar com a mídia e a sociedade foram sendo modificados gradativamente nos últimos anos. Por um lado, o STF, aquele estranho desconhecido, passou a figurar nas manchetes de jornais, capas de revistas, telejornais, rádio, blogs e redes sociais, mas por outro, a relação entre o Judiciário e os meios de comunicação ainda é marcada por muitos encontros e desencontros.

Imaginar uma sociedade totalmente transparente, um mundo que seria governado sem instituições, é simplesmente uma utopia. [...] A mídia constitui uma 
autoridade bem real, porém desconcertante, uma vez que é inconsistente, inconstante e inconsequente, o oposto de uma instituição referenciada e bem situada, estável e operante (GARAPON, 1999, p. 92-93).

Para Garapon (1999), alguns juízes utilizam-se da mídia estrategicamente, tanto para defenderem-se de críticas feitas ao poder Judiciário quanto para uma maior aproximação entre justiça e população. Mas caberia aos juízes adotar comportamentos estratégicos? Em que medida o discurso midiático interfere na crescente visibilidade dos atores judiciais, especialmente dos ministros do STF? Claro que nem toda esfera pública se reduz a imagens ou manipulações simbólicas, mas "[...] a comunicação de massa se tornou o canal mais importante para a circulação de informação [...] de vários tipos, e toda tentativa de repensar a natureza e o papel da ideologia nas sociedades modernas deve prestar uma atenção total a esse desenvolvimento." (THOMPSON, 2008, p. 135).

A partir de uma amostra considerável de reportagens veiculadas de 1979 a 1999 sobre o STF, utilizando como referência as notícias veiculadas em dois dos maiores jornais de São Paulo (Folha de S. Paulo e O Estado de S. Paulo), Fabiana Luci de Oliveira concluiu que o Tribunal "buscou transformar a imagem de que desfrutava na opinião pública, passando de uma situação em que era identificado como alheio à realidade e às necessidades do país, à imagem de instituição de importância central para o desenvolvimento da nação." (OLIVEIRA, 2004, p. 101).

Entretanto, a popularização do STF e de seus ministros no imaginário popular foi uma longa construção. As alterações na percepção colhida junto aos dois maiores jornais de São Paulo formam uma abrangente imagem de como o papel desempenhado pelo STF foi sendo descrito e absorvido pelos formadores de opinião - e, consequentemente, pode-se inferir que tenham tido impacto sobre 
o imaginário de seus leitores. Quando se iniciou a abertura política, o Tribunal passou a manifestar-se com maior frequência e a buscar novamente seu espaço entre os poderes políticos, repovoando o imaginário popular como verdadeiro contraponto às questões políticas em disputa.

Mas talvez a maior transformação em termos de imagem pública do Supremo tenha ocorrido a partir de 2002, com a criação da TV Justiça. 8 A transmissão em tempo real das sessões plenárias do STF por intermédio da TV Justiça revela algumas mudanças em relação às práticas judiciais. Em vez de audiências reservadas e deliberações a portas fechadas, como na maioria dos tribunais do mundo, aqui se julga sob o olhar das câmeras de televisão.

Sob a presidência do ministro Marco Aurélio, o STF passou a veicular ao vivo suas sessões de julgamento, transmitindo-as em canal de televisões a cabo e por satélite. Os ministros do Supremo, transformados em atores da teledramaturgia jurídica, passaram a sofrer uma superexposição midiática, cujos efeitos positivos ou negativos não são consenso na literatura acadêmica.

Em dissertação sobre as formas de veiculação das decisões do STF, Mariana Ferreira Cardoso da Silva apontou algumas das fragilidades da publicidade irrestrita que sujeita não só as decisões, mas todo o debate das sessões de julgamento do STF:

No caso do STF, a publicidade, aparentemente, não é um problema, na medida em que todos os acórdãos são publicados e disponibilizados na internet. [...] Há, ainda, desde 2002, a transmissão televisiva das sessões de julgamento por intermédio da TV Justiça. [...] A publicidade não assegura a cognoscibilidade das decisões

8 A TV Justiça, canal de televisão administrado pelo Supremo Tribunal Federal, foi criada pela Lei 10.461 de 17 de maio de 2002 (BRASIL, 2002). A emissora é a primeira rede pública a transmitir ao vivo os julgamentos do Plenário da Suprema Corte, além de ter uma programação exclusivamente voltada para o noticiário jurídico. Com sede no Supremo Tribunal Federal, a TV Justiça iniciou suas atividades em 11 de agosto de 2002 e hoje é veiculada a cabo, por satélite (DHT), antenas parabólicas e internet. 
tribunal. Pelo contrário, ao inibir a deliberação e a construção colegiada das decisões, é um fator de estimulo à produção prévia de votos e à intransigência individual no debate televisionado, resultando em decisões menos objetivas, mais extensas e sem unidade de fundamentação (SILVA, 2014, p. 75-76).

De certo modo, estas iniciativas empreendidas pelo Judiciário são uma tentativa de formar uma imagem positiva junto à população brasileira e, assim, tentar legitimar-se como um poder democrático. Entretanto, nem sempre a imagem que o Poder Judiciário idealiza sobre si mesmo se aproxima da imagem retratada pelos meios de comunicação, pois as condições de produção e reprodução dos discursos e das práticas judiciais estão atreladas a diferentes concepções políticas, ideológicas e históricas.

A midiatização de processos judiciais pode gerar julgamentos precoces e nocivos ao futuro andamento processual, principalmente no que tange a aplicação das garantias constitucionais. O tempo da notícia é completamente distinto do tempo do processo, ou seja, há diferenças consideráveis das dinâmicas entre a lógica midiática (dominada pela instantaneidade) e a lógica do processo judicial (fundamentado nos princípios da ampla defesa e do contraditório) têm provocado conflitos questionáveis sob o ponto de vista ético e democrático.

Se por um lado a exibição das sessões do STF traz maior transparência às atividades judiciais e aproxima o Poder Judiciário da população, por outro a exposição exagerada dos ministros pode gerar pressões e conflitos, ou seja, por mais que essas transmissões possam popularizar a corte, sua forma de atuação e seus atores, também atraem holofotes sobre suas cisões e a individualidade de cada ministro.

É o que se pode ler na reportagem de Luiz Maklouf Carvalho, em matéria de veiculada em duas edições da revista Piauí, de cunho satírico e reportagens de maior qualidade literária. O tom dos artigos versou sobre os bastidores da tomada de decisões no Supremo, 
descrevendo em minúcias os perfis dos ministros da época (2010) e suas relações com a mídia e as sessões televisionadas:

Conhecido pela linguagem poética com que tempera seus votos, Ayres Britto é dos ministros que nunca esquecem que seis câmeras de televisão captam tudo o que acontece nas sessões plenárias. Talvez perca nisso apenas para o ministro Marco Aurélio, quase um profissional. Britto também é bom em elaborar frases com grande chance de repercutir nos jornais no dia seguinte. A última que fez sucesso, no julgamento do habeas corpus do governador José Roberto Arruda foi: "Infelizmente, há quem chegue às maiores alturas para cometer as maiores baixezas." (CARVALHO, 2010, p. 35).

Além da intimidade de determinados ministros com as câmeras e a exposição pública, Carvalho destaca a opinião do exministro Ayres Britto sobre os perigos do vedetismo e do culto da personalidade, sem resistir, entretanto, a expor sua reprovação com relação ao comportamento de colegas de corte:

“Os ministros são figuras midiáticas e têm que saber administrar essa notoriedade", ele disse. "Eu não me sinto estrela, nem pop star, e nem assediado. Encaro com a maior naturalidade. Se me pedirem para tirar dez fotos, eu tiro as dez. Os ministros não são apenas julgadores, eles têm satisfações a dar ao público. É um dever se comunicar, desde que esse contato não resvale para o vedetismo e o culto da personalidade." A última frase é um recado é para Gilmar Mendes "Há um de nós que fala demais", respondeu Ayres Britto, e foi em frente: "O Gilmar é agressivo, rude, provocativo. Usa uma linguagem que ofende as pessoas. E não há necessidade disso. Dá para combinar leveza e firmeza." (CARVALHO, 2010, p. 36).

Eis, portanto, a delicada transição da exposição pública do STF, do anonimato de uma corte inexpressiva nos debates públicos e sem relevância no ambiente político no período anterior à carta de 1988 à superexposição midiática das sessões ao vivo, a partir de 2002, sendo 
o termo "supremocracia" cunhado por Vieira (2008) para referir-se à autoridade do STF em detrimento dos demais poderes da República.

Embora a publicidade das sessões de julgamento no STF tenha inegável guarida no princípio da publicidade dos atos da administração pública (art. 37) e do Judiciário (art. 93, IX), não há consenso em torno dos benefícios (em termos de qualidade de prestação jurisdicional) da veiculação pública de todas as sessões e deliberações da corte. Há, ao contrário, uma associação possível entre a veiculação ao vivo das sessões e seus efeitos negativos no comportamento dos ministros, inibindo o debate franco e estimulando a produção prévia de votos, em lugar do diálogo com os demais membros da corte. (SILVA, 2014, p. 77-78).

Em comparação com outras cortes, o alto grau de exposição pública do nosso STF é de fato uma exceção. O STF se expõe ao público de forma muito mais ostensiva do que em outros países, como os EUA e a França, onde as sessões das cortes constitucionais são mantidas longe dos olhares ${ }^{9}$ do grande público.

Na Supreme Court norte-americana são admitidos visitantes para os argumentos orais e o resumo da deliberação, mas são proibidas fotos e filmagens, sendo da lavra de desenhistas as únicas fontes de imagens dos julgamentos (MANZANO, 2013; SCHUBERT, 1965, p. 18). Sobre as altas cortes na jurisdição francesa, a exposição é ainda menor! Os segredos dos julgamentos nos conseils franceses são tão

9 Cumpre salientar que as comparações sobre visibilidade do STF com a corte constitucional dos Estados Unidos leva em consideração apenas a exposição pública das sessões de julgamento. Os EUA é um dos países que mais desenvolveu os estudos sobre Poder Judiciário e exibe farta bibliografia sobre a corte, com destaque para as biografias de ministros, popularizadas desde a década de 1960 por diversos autores (em especial Alpheus Thomas Mason, biógrafo dos ministros Brandeis, Harlan e Taft). Trata-se de outra forma de construção da imagem pública da corte constitucional, prescindindo da publicidade das sessões de julgamento. Há ainda um debate público muito intenso quando da indicação de um novo ministro à corte, com ampla discussão sobre suas credenciais para o cargo. Quem sabe estes pontos também possam nos ajudar a pensar as formas de visibilidade e de construção de imagem pública em pesquisas futuras. 
protegidos que para realizar as observações etnográficas do Conseil Constitutionnel, Bruno Latour afirma que só lhe foi permitido assistir às sessões de instrução. As sessões de deliberação somente podem ser vistas por egressos da Escola Nacional de Administração (ENA, de onde saem os quadros da alta administração pública francesa), juízes ou estagiários (LATOUR, 2004, p. 30).

No país dos tucanos e jabuticabas, as sessões são - pasmem - muito mais acessíveis do que no hemisfério norte. Se Bruno Latour desejasse escrever uma etnografia do STF, poderia fazê-lo de casa, sentado confortavelmente em seu sofá, assistindo as sessões por meio da TV Justiça ou lendo as notícias em tempo real veiculadas no twitter.

Entretanto, o conforto doméstico cobra seu preço: Os debates e julgamentos são públicos, mas não necessariamente transparentes. A tensão entre a franca publicidade da corte (com a veiculação televisiva dos julgamentos do STF) e seu déficit de transparência é exposto por Virgílio Afonso da Silva e Conrado Hübner Mendes. Os autores afirmam que a falta de clareza das decisões da corte ofusca os benefícios colhidos da ampla publicidade, criando o que chamam de populismo judicial: “Transmissões ao vivo e acórdãos disponíveis na internet, entre outras medidas, criaram um mito de transparência que precisa ser desconstruído." (MENDES; SILVA, 2009, p. 1).

\section{O Julgamento do Mensalão: O Supremo em capas de revistas}

No Brasil o episódio político que ficou conhecido como "mensalão" ganhou ares de "escândalo midiático", com enorme visibilidade e uma pluralidade de desdobramentos. O julgamento da Ação Penal $470^{10}$ foi um marco na história do Judiciário brasileiro, sendo iniciado pelo pleno do STF em 02 de agosto de 2012 e concluído em dezembro de 2012, após 53 sessões plenárias inteiramente dedicadas

10 O Inquérito 2245 (autuado no STF em 2005) foi convertido na Ação Penal 470 em 2007. 
ao exame da ação. ${ }^{11}$ A Ação Penal 470 (composta por mais de 70 mil páginas, 313 volumes, 501 apensos e 40 acusados) passou por várias fases e só foi considerada encerrada em agosto de 2014 (BRASIL, 2015).

Todas as sessões do julgamento foram transmitidas ao vivo $^{12}$ tanto pelos canais oficias do STF quanto por outros canais de televisão, que reproduziram as sessões e dedicaram boa parte de sua programação ao caso, fazendo uma cobertura intensa, com participação de jornalistas, juristas e professores, comentando, avaliando e respondendo dúvidas dos telespectadores. É interessante observar como os jornalistas tentaram "traduzir" aos espectadores a linguagem, os termos e os conteúdos jurídicos deste processo. Se já é difícil explicar qualquer julgamento jurídico, imagina este que se transformou em um produto midiático, conduzido e moldado para ocupar a grade da programação televisiva.

Essa grande repercussão gerou muitos discursos, teses, controvérsias e tensões, tanto jurídicas quanto políticas. Contudo, cabe salientar, que a complexidade jurídico-política do caso não será enfatizada, mas as condições de visibilidade midiática e as imbricações da exposição exagerado dos atores judiciais para a construção da imagem do STF. Neste período, diferentes enunciados a respeito do julgamento foram produzidos, todos os envolvidos tiveram algum tipo de exposição nos meios de comunicação, tudo pode ser abordado de forma midiatizada, desde a postura dos ministros, do PGR, dos réus e dos advogados.

Chamando 2012 de o 'ano pop' do STF, Marcelo Novelino descreve que em agosto, primeiro mês de julgamento do mensalão, o número de menções à corte na mídia (em jornais, revistas, portais,

11 O período mencionado não compreende a fase do julgamento dos embargos de declaração e dos embargos infringentes.

12 “O julgamento do mensalão pode garantir um presente de aniversário especial de 10 anos para a TV Justiça [...] a maior audiência da sua história. Por no mínimo um mês, será transmitido ao vivo o mais popular julgamento da história do Supremo Tribunal Federal." (BERGAMASCO; RECONDO, 2012). 
blogs, etc.) teria quadruplicado (NOVELINO, 2013, p. 267). No caso do relator da ação, o ministro Joaquim Barbosa, além de gozar de notório reconhecimento nos meios de comunicação, estampando capas de revistas, jornais, noticiários e páginas de redes sociais, também suscitou o desejo (de parte da população) até de uma possível candidatura às eleições presidenciais. Vale lembrar a preocupação de Maus (2002), a respeito da atuação de juízes enquanto celebridades midiáticas e as críticas do "mito do herói".

Para fins do artigo, selecionamos apenas capas de revistas semanais de circulação nacional, produzidas nos anos de 2012 e 2013, em que o julgamento da AP 470 pelo STF fosse utilizado de forma explícita. O recorte foi bem específico, as capas que se referiam somente ao "escândalo" político do mensalão não foram consideradas. Em nosso entender as capas de revistas funcionam como enunciados que podem ser analisados enquanto acontecimentos discursivos. Ao trabalhar com as capas tem-se a oportunidade de investigar, à maneira de Foucault (2004), as condições de produção, reprodução e aparecimento de determinados enunciados como algo que irrompe num certo tempo, num certo lugar, isto é, em um dado momento histórico. Assim, adotamos a noção de enunciado como um acontecimento "que nem a língua nem o sentido podem esgotar inteiramente." (FOUCAULT, 2004, p. 31).

Tendo em vista a emergência de enunciados durante o período do julgamento da AP 470, não levamos em consideração um recorte temporal maior ${ }^{13}$. Não se buscou uma única verdade em relação à construção midiática sobre o STF e seus ministros, mas sim os efeitos de sentido (re)produzidos a partir das contradições eheterogeneidades discursivas. Entendemos a mídia como um dos campos que mais expõe a luta entre diferentes discursos e impõe sentidos. Em outras palavras, é como se a maioria dos discursos sofresse uma mediação

13 Há certa ausência de capas de revista (específicas) sobre o STF e seus ministros antes de 2012. 
dos meios de comunicação, mas como nos alerta Foucault (2004, p. 146), o discurso não tem apenas um sentido ou uma verdade, mas uma história.

A escolha pelas capas também se justifica pela maneira como os processos de produção de notícias funcionam, isto é, a capa de uma revista precisa produzir um efeito imediato de atualidade, despertar a atenção e aguçar o desejo dos leitores em adquirir aquele produto. Em última instância, é pela capa que a revista consegue seu maior ou menor número de vendas. Além disso, aliada a outras estratégias, a capa também elucida as diferentes formas de se produzir notícias, dependendo das convicções políticas e ideológicas de cada veículo de comunicação. Os elementos gráficos e um bom título são essenciais para captar a atenção dos leitores, as escolhas das cores, da fotografia e da diagramação precisam estar em sintonia para deixar claro qual será o tom da reportagem.

Ao todo foram encontradas vinte e cinco (25) capas $^{14}$, publicadas nos anos de 2012 e 2013, que fazem referência expressa ao julgamento do "mensalão" pelo STF.

Quadro 1 - Quantidade de capas sobre O Julgamento do "Mensalão" por ano.

\begin{tabular}{|c|c|c|}
\hline Revistas & Ano 2012 & Ano 2013 \\
\hline Veja & 05 & 05 \\
\hline Época & 03 & 02 \\
\hline Isto é & 02 & 03 \\
\hline Carta Capital & 03 & 02 \\
\hline
\end{tabular}

Fonte: Elaboração dos autores a partir das 25 capas de revista publicadas entre 2012 e 2013.

O quadro acima retrata a quantidade de capas sobre o tema produzidas por cada revista. Com o objetivo de servirem apenas de

14 Consideramos as 25 capas num universo de 416 capas ( $4 \times 52$ semanas por ano/ 2 anos) bem representativas, visto que equivalem a mais de $5 \%$ das capas. Só na Revista Veja são 10\%. 
exemplo, fizemos um recorte com breves apontamentos, mostrando as convergências e divergências na abordagem do julgamento. Em termos quantitativos a revista Veja foi a que mais produziu capas com a temática do "mensalão". A postura da revista oscilou entre dar credibilidade ao STF e, principalmente ao relator da Ação, o ministro Joaquim Barbosa, e depois, na fase do julgamento da admissibilidade dos embargos infringentes, adotar uma postura de descrédito com a justiça.

A emblemática capa (figura 1) com a fotografia do Ministro Joaquim Barbosa ainda criança e os dizeres: "O menino pobre que mudou o Brasil" provocou reações controvérsias a respeito da postura do ministro. Essa ideia do herói, salvador do Brasil contra a corrupção, também circulou por outros veículos de comunicação.

Figura 1 - Capa da Revista Veja de 10/10/2012

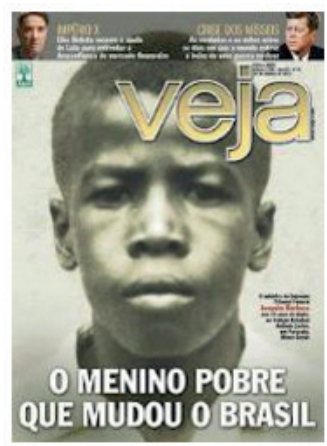

Fonte: Revista Veja

A capa da edição seguinte (figura 2) apresenta a figura de fogos de artifícios sob a bandeira do Brasil em comemoração a condenação dos réus do "mensalão". Na parte superior encontram-se os seguintes dizeres: "O Brasil tem razão de comemorar. A condenação dos mensaleiros lava a alma de todos os brasileiros vítimas dos corruptos." 
Figura 2 - Capa da Revista Veja de 17/10/2012

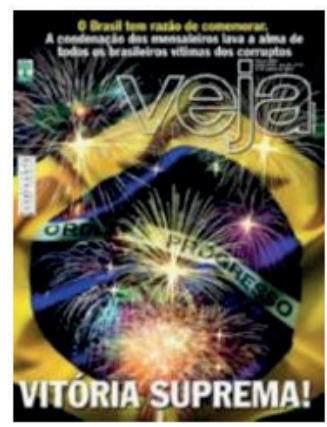

Fonte: Revista Veja

Contudo, a ideia de "vitória suprema" e os elogios à postura do Supremo mudam completamente na edição seguinte (figura 3), logo após o voto do ministro Celso de Mello a favor da admissibilidade dos embargos infringentes. A capa de fundo preto estampa a imagem da deusa da Justiça de cabeça baixa (se curvando) e os dizeres: "Brasília, 18 de setembro de 2013" (data do voto do Ministro Celso de Mello).

Figura 3 - CAPA DA Revista VeJA DE 25/09/2013

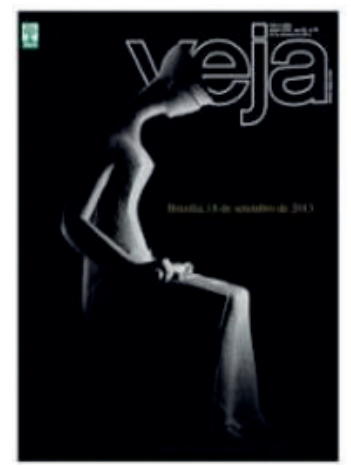

Fonte: Revista Veja

Esta capa reflete bem a mudança de postura e contrasta com as capas produzidas no final de 2012 - a revista vai da festa ao luto. Houve, naquele momento, uma grande pressão e especulação dos meios de comunicação sobre o voto de minerva do ministro quanto à admissibilidade dos embargos. $\mathrm{O}$ dia 18 de setembro ficou marcado 
pela mudança de tom e postura, por parte da mídia, com relação ao julgamento. Em seu voto, o ministro Celso de Mello fez uma crítica direta a respeito da interferência do clamor público nos processos:

[...] os julgamentos do Supremo Tribunal Federal, para que sejam imparciais, isentos e independentes, não podem expor-se a pressões externas, como aquelas resultantes do clamor popular e da pressão das multidões, sob pena de completa subversão do regime constitucional dos direitos e garantias individuais e de aniquilação de inestimáveis prerrogativas essenciais que a ordem jurídica assegura a qualquer réu mediante instauração, em juízo, do devido processo penal (BRASIL, 2013).

Até então não havia circulado nos meios de comunicação a discussão sobre as regras para a indicação dos ministros, mas a partir desse dia o questionamento sobre o caráter democrático ou não sobre a composição da Corte veio à tona e passou a circular nos jornais e revistas. Uma das capas produzidas pela revista Isto é durante o mês de setembro de 2013 (figura 4), retoma a imagem de herói, combatente, salvador, do Ministro Joaquim Barbosa após o voto do ministro Celso de Mello.

Figura 4 - CAPA DA REvista ISTOÉ DE 18/09/2013

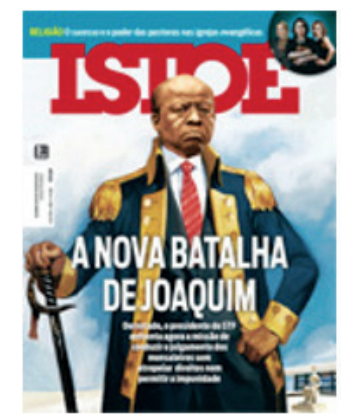

Fonte: Revista Isto É

Tendo em vista a construção da imagem do ministro Joaquim Barbosa, é importante retomar a visão do herói, no sentido do fascínio, da ilusão, ressaltada por Schwartzenberg (1978), em razão dos 
vários tipos de líderes presentes na sociedade do espetáculo. "Cada líder se dedica ao mesmo exercício: surpreender, cativar e agradar. Cada um deles concebe a política como uma arte de sedução." (SCHWARTZENBERG, 1978, p. 62).

A revista Época, por sua vez, trouxe uma edição especial em novembro de 2013 com a imagem dos políticos condenados no julgamento (figura 5). O conhecido enunciado do presidente Lula "nunca antes neste país" é ressignificado nesta capa. Em outra perspectiva, a revista Carta capital aborda a fase de admissibilidade dos recursos fazendo referência às pressões midiáticas com relação ao voto do ministro Celso de Mello.

\section{Figura 5 - CAPA DA REvista ÉPOCA DE 17/11/2013}

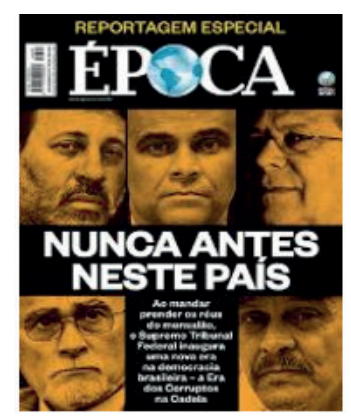

Fonte: Revista Época

Figura 6 - CAPA DA REvista CARTA CAPITAL DE 12/09/2013

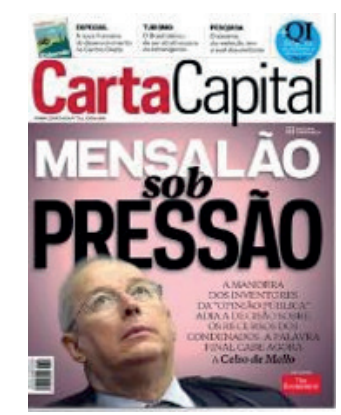

Fonte: Revista Carta Capital. 
A partir destes exemplos, percebemos como algumas capas, enquanto enunciados/imagens, produzem diferentes significados e percepções sobre o mesmo fato. A imagem da Justiça oscilou não só no curto período de tempo como também pelo suporte de divulgação. As 25 capas rendem análises muito mais cuidadosas e aprofundadas sobre o tema, mas neste artigo, buscamos apenas ilustrar um pouco as reflexões teóricas sobre a relação conflituosa do Judiciário e os meios de comunicação. Nesse sentido, a imprensa pode tanto auxiliar na compreensão do funcionamento da Justiça como produzir distorções que prejudiquem o relacionamento da sociedade com o Judiciário. No caso específico do "mensalão" vários fatores e interesses contribuíram para o processo de espetacularização do julgamento. O envolvimento de líderes políticos importantes e a narrativa construída pelo relator da ação provocaram tensões e oscilações diferentes, tanto entre os Poderes quanto em relação aos meios de comunicação.

\section{O STF como Produtor da Informação}

Que o Estado brasileiro se comunica bastante com a sociedade, ninguém desconhece. Os poderes da República - o Executivo, o Legislativo e o Judiciário - têm emissoras próprias de rádio e televisão, e não apenas no âmbito federal. [...] O Estado, no Brasil, faz de tudo para que seus recados batam nos olhos e nos ouvidos da nossa gente. Faz de tudo para aparecer (BUCCI, 2015, p. 15).

Na frase em epígrafe, Eugênio Bucci descreve a comunicação pública no Brasil no contexto do que chama de "Estado de Narciso", o uso da comunicação pública a serviço dos interesses particulares. Embora suas críticas sejam direcionadas primordialmente aos detentores de mandato eletivo - titulares dos poderes Executivo e Legislativo -, é possível encontrar rastros deste Estado de Narciso junto ao Poder Judiciário. 
OBrasil conta com 91 Tribunais. ${ }^{15}$ Cada um destes tribunais tem seus portais institucionais e os servidores encarregados de alimentar seus respectivos sites com notícias e informações variadas. Dentre estes, o mais organizado em termos de veiculação de informações é o Supremo Tribunal Federal (STF).

Se no tópico anterior pudemos evidenciar o discurso midiático em relação ao STF e seus ministros, neste tópico pretendemos expor a teatralidade das informações veiculadas pelo próprio STF, no recorte de como a corte escolhe se fazer representar por meio de seus mecanismos próprios de produção e veiculação de notícias. Neste aspecto, exsurge o espetáculo de forma sistemática e organizada pelo próprio ator principal, como proposto por Schwartzenberg (1978, p. $14)$.

O STF tem sua própria agência de notícias, encarregada de produzir diariamente releases contendo informações sobre os julgamentos, sobre a agenda dos ministros e sobre os debates ocorridos. O Tribunal conta também com um programa de rádio (rádio justiça), um canal de televisão (TV justiça) e perfis oficiais no portal de vídeos youtube ${ }^{16}$ e na rede social twitter ${ }^{17}$, veiculando notícias em português e em inglês.

A assessoria de comunicação do STF é composta por uma equipe de jornalistas. A eles incumbe alimentar o portal de notícias do STF com toda sorte de notícia que é produzida pela corte, registrando desde visitas institucionais de outros tribunais a resultados de julgamentos, passando pela agenda diária do presidente do supremo

15 São 27 Tribunais de Justiça dos Estados e do Distrito Federal, 27 Tribunais Regionais Eleitorais, 24 Tribunais Regionais do Trabalho, 5 Tribunais Regionais eleitorais, 4 Tribunais Superiores, 3 Tribunais de Justiça Militar e um Supremo Tribunal Federal.

16 O youtube é um portal de compartilhamento de vídeos com mais de um bilhão de usuários pelo mundo.

17 O twitter é uma rede social caracterizada pelas mensagens curtas, de no máximo 140 caracteres, que conta com meio bilhão de cadastrados, dos quais mais de 41 milhões são brasileiros. 
e por honras e distinções que porventura algum de seus membros venha a ser agraciado.

Observando a forma como as notícias são veiculadas, é notável perceber a grande preocupação em indicar nominalmente o ministro responsável por esta ou aquela decisão, como se demonstra na reprodução da tela do portal de notícias do dia 04 de dezembro de 2015:

Figura 8 - Página do Portal STF- em 4/12/2015

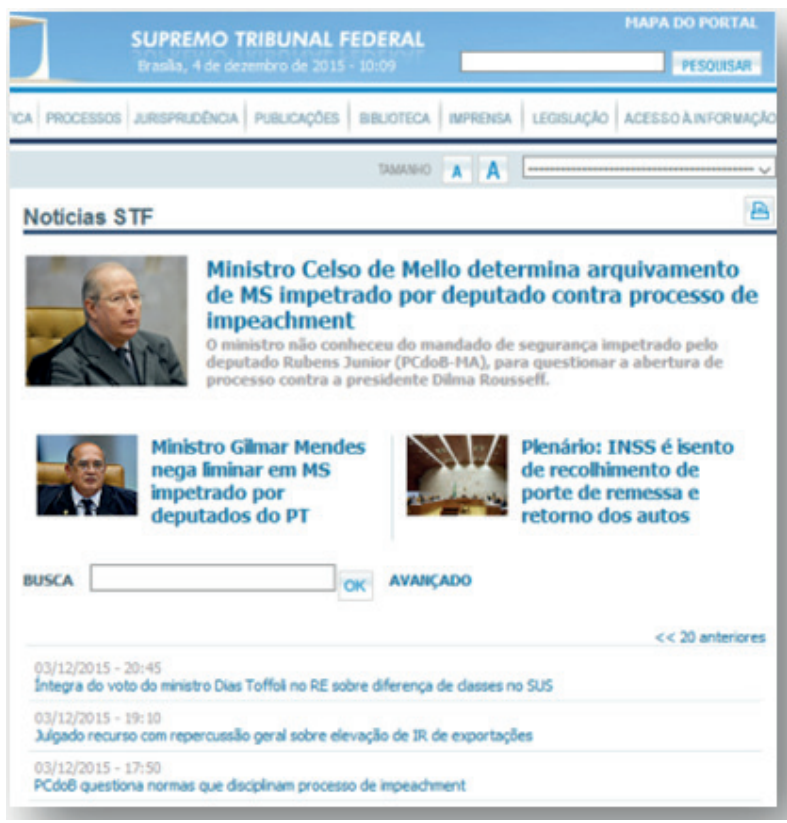

Fonte: web.archive.org.

A primeira informação que salta aos olhos é a veiculação das fotos em primeiro-plano dos ministros Celso de Melloe Gilmar Mendes. Além das imagens, 3 das 6 manchetes de reportagens disponíveis traz em destaque o nome do ministro responsável pela decisão noticiada, enquanto apenas uma das 6 dá ênfase ao trabalho coletivo: "Plenário: INSS é isento de recolhimento [...]."

Para verificar se essa aparente ênfase nos feitos individuais dos ministros é um padrão que se mantém no tempo, colhemos amostras 
de 10 páginas dos últimos 5 anos, disponíveis por meio do serviço "web.archive.org" que guarda algumas amostras ${ }^{18}$ de páginas de sites que se modificam ao longo do tempo, tornando possível investigar como estavam visualmente as primeiras páginas do portal de notícias do STF duas vezes por ano para datas do passado.

2010

Figura 9 - Página do Portal STF - em 18/4/2010 e 16/5/2010

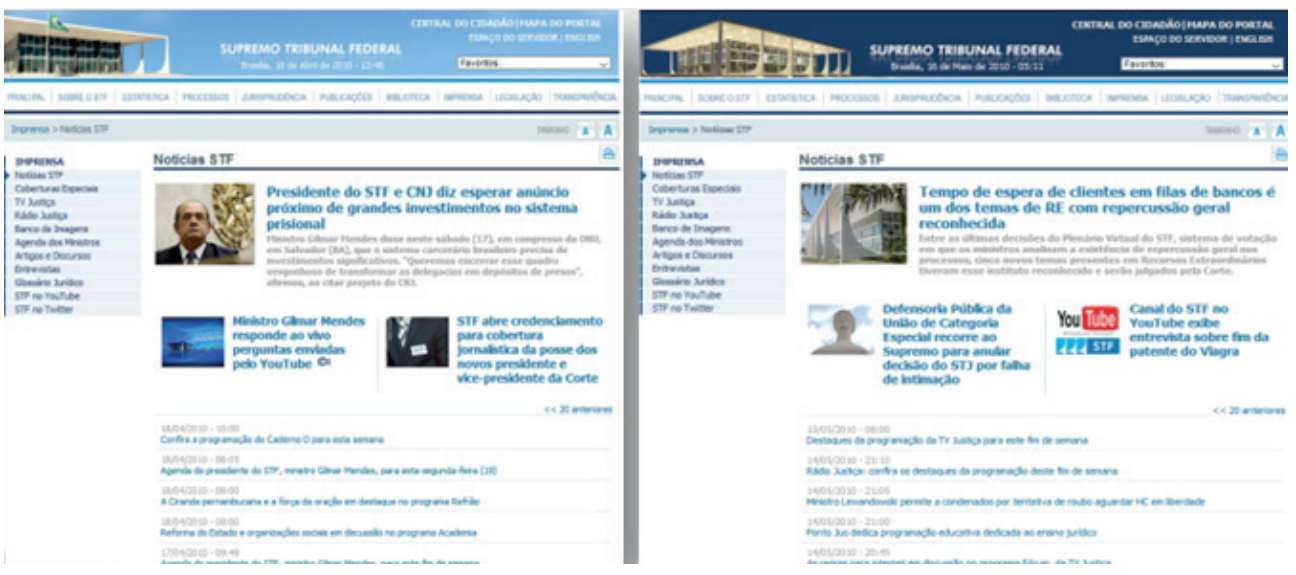

Fonte: web.archive.org.

18 A busca foi realizada inserindo o endereço do site <www.stf.jus.br/portal/cms/ listarNoticiaUltima.asp > dentro do serviço <web.archive.org > . Ali haviam 320 capturas realizadas em datas aleatórias, entre 19 de setembro de 2008 a 24 de agosto de 2015 . O repositório conta com aproximadamente um arquivo (página) por semana neste período de tempo. Infelizmente, como o sistema não guarda o fac-símile da integralidade das páginas existentes, não foi possível investigar como foram veiculadas as notícias em algumas datas específicas, como dias de grandes discussões no plenário ou questões de grande repercussão. Para este fim, entretanto, pode-se utilizar a ferramenta de busca disponível no próprio site do $\mathrm{STF}$, na qual é possível filtrar as notícias por intervalo temporal. 
Figura 10 - Página do Portal STF - em 10/2/2011 e 8/5/2011

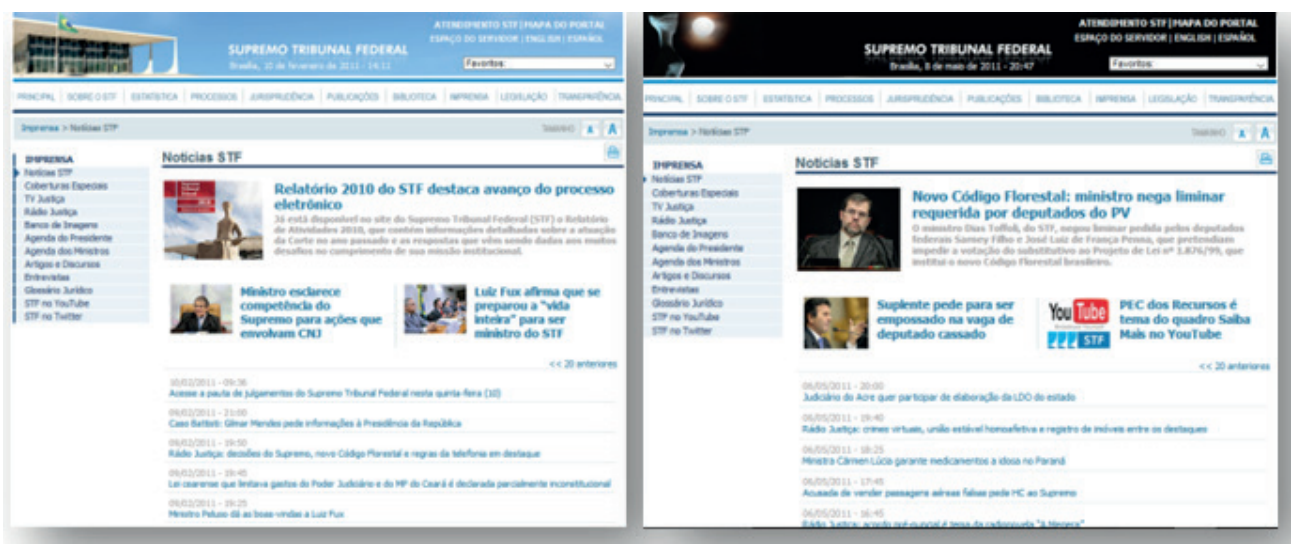

Fonte: web.archive.org.

2012

Figura 11 - PÁgina do Portal STF - EM 5/4/2012 E 29/8/2012

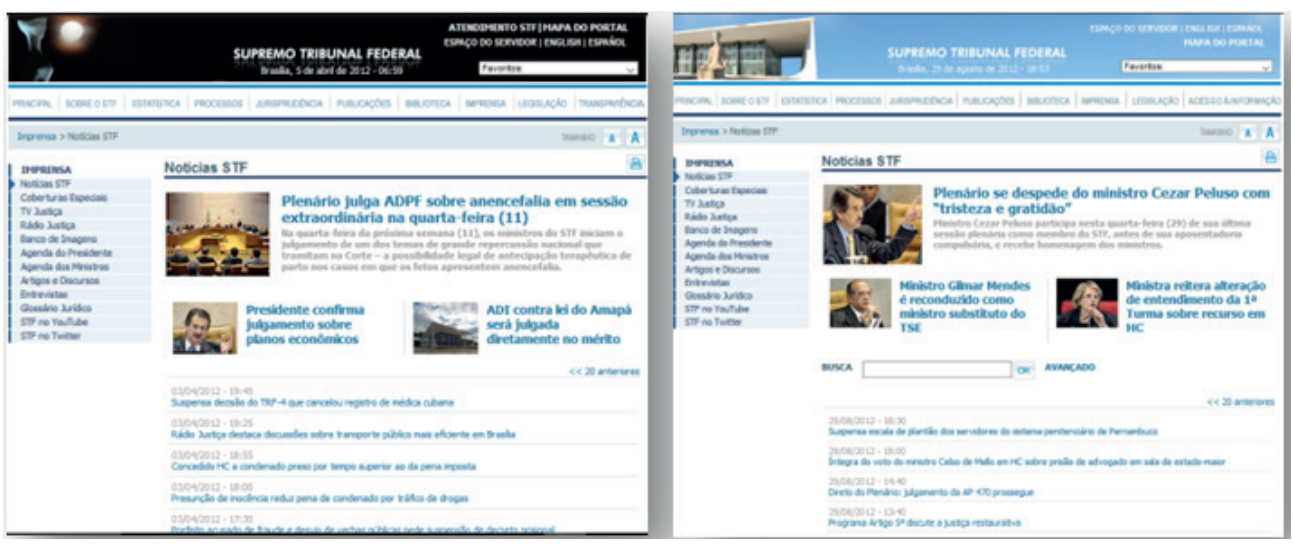

Fonte: web.archive.org. 
2013

Figura 12 - Página do Portal STF - em 13/6/2013 e 3/8/2013

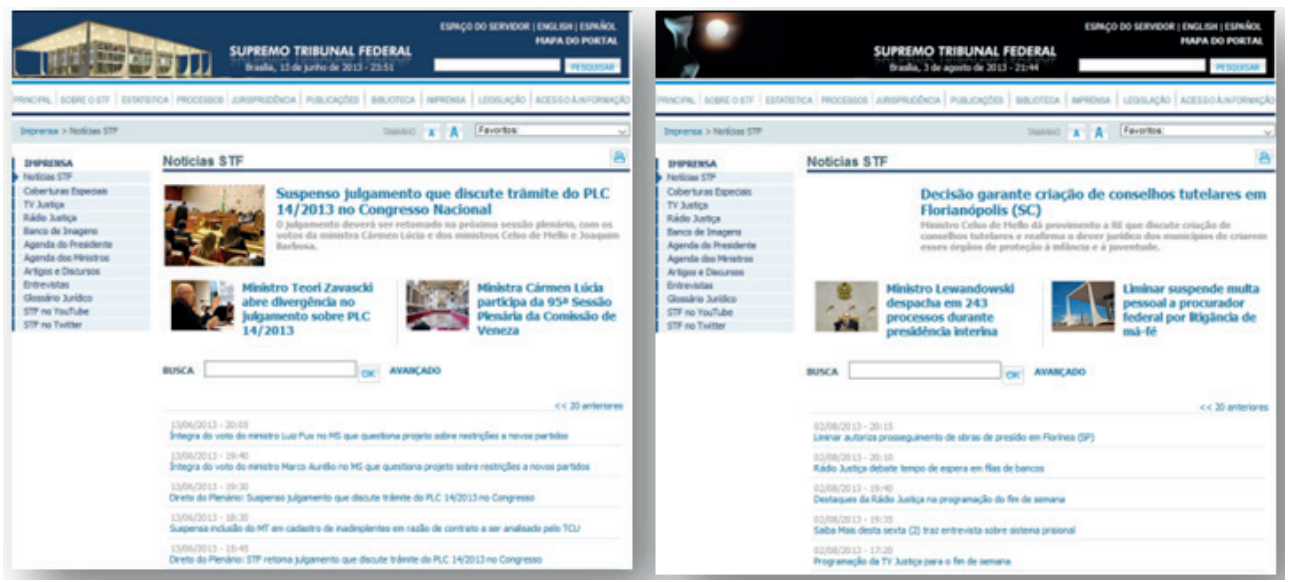

Fonte: web.archive.org.

\section{4}

Figura 13 - Página do Portal STF - em 12/8/2014 e 25/11/20014
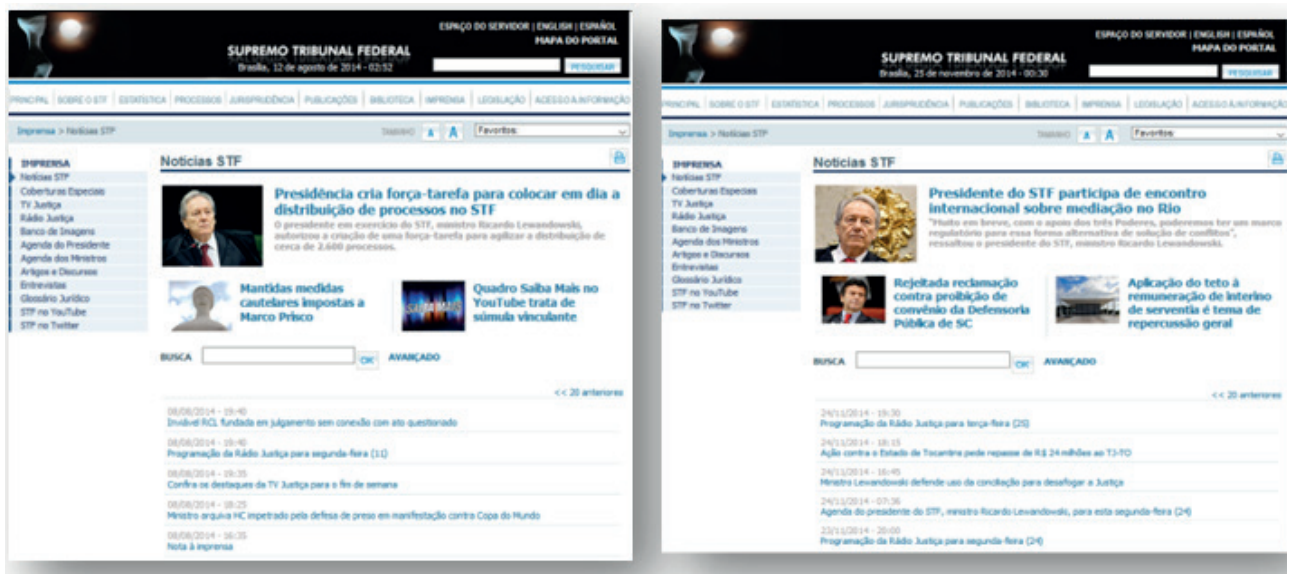

Fonte: web.archive.org.

$\mathrm{Na}$ amostra de 11 páginas colhidas, existem 32 imagens $^{19}$. Destas, 14 veiculam fotos de ministros da Corte. Embora a amostra

19 Há 3 imagens por página, mas uma imagem (de 03/08/2013) não foi recuperada pelo mecanismo de arquivo temporal 
seja pequena, no universo colhido, quatro de cada dez fotos expostas estampa a imagem de algum dos ministros do STF.

Ainda, na parte textual, onde constam as chamadas (ou headlines) das notícias, foram mencionados nomes de algum dos ministros em 29 das 86 chamadas constantes da amostra. Isso equivale a veicular o nome dos ministros em uma de cada três notícias.

Diante deste panorama - ainda que retirado de uma pequena amostra -, parece que a comunicação pública do STF não tem a pretensão ou o cuidado de fortalecer a imagem coletiva do STF. Ao contrário, há um evidente destaque individual para alguns dos onze ministros que compõem a corte.

Quadro 2 - Ministros e número de destaques nas Chamadas de notícias, EM ORDEM DECRESCENTE

\begin{tabular}{|c|c|c|c|}
\hline Ministro & Destaques & Ministro & Destaques \\
\hline Gilmar Mendes & 7 & Cezar Peluso & 2 \\
\hline Ricardo Lewandowski & 6 & Dias Toffoli & 2 \\
\hline Carmen Lúcia & 3 & Joaquim Barbosa & 1 \\
\hline Luiz Fux & 3 & Marco Aurélio & 1 \\
\hline Celso de Mello & 2 & Teori Zavascki & 1 \\
\hline
\end{tabular}

Fonte: Elaboração dos autores a partir das 11 páginas disponíveis de 18/04/2010 a 04/12/2015 em <www.stf.jus.br/portal/cms/listarNoticiaUltima.asp>, via <web.archive.org>.

É curioso notar que o ex-ministro Joaquim Barbosa, a despeito da grande exposição midiática no ano de 2012, esteja timidamente com apenas um destaque nas amostras ${ }^{20}$ colhidas no portal de notícias entre 2010 e 2015.

20 Uma consideração deve ser feita com relação ao período de amostragem da lista e as nomeações para o STF que alteraram a composição da corte. Os Ministros Luiz Fux e Teori Zavascki passaram a integrar a corte apenas em março de 2011 e novembro de 2012, respectivamente, ficando prejudicados na amostragem. Da mesma forma o ministro Cezar Peluso deixou a corte em agosto de 2012, estando em apenas parte da amostragem. Ainda sem menções na lista elaborada, embora parcialmente presentes no STF no período, estão os ministros Ayres Britto, aposentado em novembro de 2012 e Rosa Weber, empossada em novembro de 2011. 
Outra reflexão que os dados colhidos provocaram tem relação com a modificação da linha editorial ao longo do tempo. Explicase: nas amostras colhidas, há períodos com uma concentração de informações sobre poucos ministros (2010 e 2014) e outros com uma distribuição equitativa, como parece ter ocorrido em 2013 (quando foram divulgadas as ações de sete diferentes ministros), conforme ilustra o quadro abaixo:

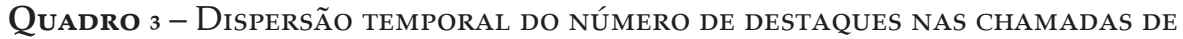
NOTÍCIAS, POR MINISTRO:

\begin{tabular}{|c|c|c|c|c|c|c|}
\cline { 2 - 7 } \multicolumn{1}{c|}{} & $\mathbf{2 0 1 0}$ & $\mathbf{2 0 1 1}$ & $\mathbf{2 0 1 2}$ & $\mathbf{2 0 1 3}$ & $\mathbf{2 0 1 4}$ & $\mathbf{2 0 1 5}$ \\
\hline Ricardo Lewandowski & 1 & & & 1 & 4 & \\
\hline Gilmar Mendes & 4 & 1 & 1 & & & 1 \\
\hline Carmen Lúcia & & 1 & & 2 & & \\
\hline Luiz Fux & & 2 & & 1 & & \\
\hline Celso de Mello & & & 1 & 1 & & 1 \\
\hline Cezar Peluso & & 1 & 1 & & & \\
\hline Marco Aurélio & & & & 1 & & \\
\hline Joaquim Barbosa & & & & 1 & & \\
\hline Dias Toffoli & & 1 & & & & 1 \\
\hline Teori Zavascki & & & & 1 & & \\
\hline
\end{tabular}

Fonte: Elaboração dos autores a partir das 11 páginas disponíveis de 18/04/2010 a 04/12/2015 em $<$ www.stf.jus.br/portal/cms/listarNoticiaUltima.asp >, via <web.archive.org>.

A amostragem muito pequena das notícias colhidas torna frágil qualquer inferência que busque descrever uma manipulação clara das informações veiculadas no portal de notícias. Feita a ressalva, haveria alguma correlação entre a veiculação de notícias e o exercício da presidência do STF?

Dito de outro modo seria possível que existisse uma orientação, um direcionamento com relação ao conteúdo das notícias, exercido por 
parte do ministro presidente ${ }^{21}$ do STF sobre o setor de comunicação da corte?

Embora não se possa afirmar categoricamente tal correlação positiva com base na pequena amostra colhida, há alguns indícios para, ao menos, alimentá-la como dúvida. Observando o quadro abaixo dos períodos de presidência de cada ministro, é possível perceber uma correlação entre o aumento de exposição, no site de notícias do STF e o período na presidência:

Quadro 4 - Ministros presidentes do STF DE 2001 A 2016, COM Destaques Para OS PERÍ́DOS dOS ANOS DE 2010 E 2014 SOB A PRESIDÊNCIA dOS MiNistros Gilmar MENDES E

RicARDo LEWANDOWSKI, RESPECTIVAMENTE

\begin{tabular}{|c|c|}
\hline Ministro & Período na presidência \\
\hline Ricardo Lewandowski & $\mathbf{2 0 1 4}$ (ago.) a 2016 (ago.) \\
\hline Joaquim Barbosa & 2012 (nov.) a 2014 (jul.) \\
\hline Ayres Britto & 2012 (abr.-nov.) \\
\hline Cezar Peluso & 2010 (abr.) a 2012 (abr.) \\
\hline Gilmar Mendes & 2008 (abr.) a 2010 (abr.) \\
\hline Ellen Gracie & 2006 (abr.) a 2008 (abr.) \\
\hline Nelson Jobim & 2004 (jun.) a 2006 (mar.) \\
\hline Maurício Corrêa & 2003 (jun.) a 2004 (maio) \\
\hline Marco Aurélio & 2001 (maio) a 2003 (maio) \\
\hline
\end{tabular}

Fonte: Elaboração dos autores a partir das informações do site <http://www.stf.jus.br/portal/ ministro/listarpresidente.asp >.

21 Cabe a ressalva de que a constatação talvez não seja tão relevante, pois é comum que o presidente de um colegiado ganhe destaque nas notícias veiculadas pelo órgão, tal como ocorre no Legislativo. Neste aspecto, a predominância de notícias sobre o ministro presidente pode ser tido mais como regra do que como exceção a demonstrar algo extraordinário. Por outro lado, a constatação não refuta a hipótese de uma espetacularização do tribunal em suas próprias notícias. Entretanto, para fortalecer este argumento seria necessário buscar suporte em bibliografia sobre critérios de noticiabilidade, composição do lide e produção da notícia, questões levantadas neste tópico, mas que demandam futuras pesquisas para pleno desenvolvimento. Agradecemos aos pareceristas anônimos pela análise que compõe esta nota. 
Em 2014, por exemplo, as notícias veiculando o nome do ministro Ricardo Lewandowski quadruplicaram após o início de seu mandato na presidência da corte. $\mathrm{O}$ mesmo pode ser constatado com relação ao ministro Gilmar Mendes, cuja presença nas notícias institucionais foi mais intensa na página colhida ainda no período de sua presidência (abril 2010).

Ademais, parece haver uma alteração na pauta de notícias até mesmo quando há substituições temporárias. Sintomática nesse sentido é a notícia de 03 de agosto de 2013, que veicula que "Ministro Lewandowski despacha em 243 processos durante presidência interina." Ora, as notícias de julgamentos não costumam veicular dados estatísticos da produtividade dos ministros. Neste caso, parece ter existido uma dose de voluntarismo para exibir a eficiência do ministro Ricardo Lewandowski - e isto, justamente quando o ministro estava na presidência interina. Não sabemos quem envia as informações à central de comunicação, nem quem decide a pauta de notícias, mas há indícios para suspeitar que o ministro no exercício da presidência teria alguma palavra sobre o conteúdo veiculado.

Em seu livro sobre os bastidores do STF, Patrícia Perrone Campos Mello aponta uma possível motivação para que o ministro Lewandowski busque enfatizar sua atuação na corte: Em contraposição à visão de herói atribuída ao ex-ministro Joaquim Barbosa, Lewandowski teria sido identificado como o vilão, sendo um dos ministros mais criticados pela opinião pública durante o julgamento do Mensalão:

As muitas sessões plenárias que debateram a ação registraram um relator extremamente aguerrido, convicto da responsabilidade de alguns dos réus, obstinado a conduzir até o fim um processo que já era considerado um marco na história política do país. Tais sessões registraram, ainda, um revisor que, desde os momentos iniciais do julgamento, se propusera a ser um "contraponto" ao relator, revelando, em algumas oportunidades, tendências 
absolutórias. [...] O ministro Joaquim Barbosa tornou-se, aos poucos, um dos homens mais populares do país. [...] O revisor do julgamento, ao contrário, enfrentou críticas e impopularidade em razão de suas divergências com o relator. Ao final da primeira fase do julgamento, afirmavase que os ministros do STF deixavam para o país "um legado político" (MELLO, 2015, p. 361-362).

Visto como o antagonista do "herói" Joaquim Barbosa, é possível especular que o ministro Lewandowski tivesse motivação para buscar fortalecer sua imagem pública com notícias sobre sua produtividade na corte. Entretanto, para ultrapassar a mera especulação, será necessário ampliar a amostra de dados em novos estudos, buscando testar a hipótese de que os ministros atuam de forma estratégica para se manter, individualmente, sob os holofotes por meio das notícias institucionais. Outra hipótese a ser testada descrita por Bucci (2015) com relação à "Voz do Brasil" - é a de que a própria assessoria de comunicação do STF, de forma autônoma, escolha colocar em destaque o ministro que esteja a presidir a Corte, seja pela maior abundância de eventos institucionais a noticiar, seja como comportamento para "agradar o chefe".

A partir desta pequena amostra, as notícias veiculadas pelo STF em sua página institucional geram mais dúvidas do que certezas, constituindo agenda de pesquisa carente de produção acadêmica e que apresenta, a nosso ver, um terreno fértil para a descoberta de novos elementos que possam contribuir no debate sobre a judicialização e o ativismo judicial.

\section{Considerações Finais}

Ao desenvolvermos este artigo, nossas preocupações se concentravam na relação conflituosa entre Política, Judiciário e Mídia. Vimos que esta relação é bastante complexa e pode ser analisada por diferentes abordagens. Constatamos que no Brasil, em razão das 
alterações institucionais do pós-Constituição de 1988 houve uma ampliação e aprofundamento da presença do Direito na vida política e social, especialmente com a nova configuração dada ao Poder Judiciário.

A ampliação da jurisdição constitucional e atuação das cortes judiciais nas democracias contemporâneas têm provocando debates tanto nas ciências sociais e jurídicas quanto nos meios de comunicação. Além disso, percebemos que as tensões vividas entre a esfera política e a esfera jurídica estão quase sempre atravessadas pelos discursos da mídia, provocando assim, diferentes desdobramentos em relação à imagem do Judiciário, especialmente do Supremo Tribunal Federal e seus ministros.

O atual protagonismo do Judiciário pode ser visto como uma situação positiva para o contexto constitucional, desde que as decisões judiciais protejam o sistema democrático e garanta os direitos fundamentais, isto é, que haja limites impostos por uma jurisdição constitucional bem exercida. Por outro lado, quando essa atuação não respeita os limites constitucionais e as regras do jogo democrático, podemos ter enormes prejuízos à democracia.

Embora, alguns estudos mostrem que não houve um aumento (quantitativo) dos processos de cunho eminentemente políticos, percebemos uma maior repercussão midiática dos casos envolvendo questões políticas. Nesse sentido, há uma impressão cada vez maior da interferência do STF em questões que deveriam ser resolvidas no âmbito dos poderes Legislativo e Executivo e que passaram a ser amplamente influenciadas por decisões judiciais.

Logo, a interferência da mídia tanto na atuação judicial quanto na atuação parlamentar acaba influenciando sobremaneira a percepção da sociedade sobre a política e a justiça. Sabemos que é dever do Judiciário dar publicidade a seus atos e ações, incluindo-se decisões e andamentos processuais, seja de maneira direta ou através dos 
meios de comunicação, com a finalidade de proporcionar julgamentos mais justos e, ao mesmo tempo legitimar a instituição junto à opinião pública.

Entretanto, a relação entre mídia e judiciário ainda está longe de ser respeitosa e confiável, visto que os conflitos de interesse ainda provocam percepções distintas do papel de cada uma dessas instituições. Ademais, a imagem que o Judiciário quer construir de si mesmo entra em choque com a imagem construída pelo discurso midiático, pois como vimos pelas capas das revistas, as condições de produção e reprodução dos discursos e das práticas judiciais pelos meios de comunicação estão atrelados a diferentes concepções políticas e ideológicas, enquanto as notícias veiculadas pela própria corte dão ênfase à individualização de atos de ministros (em especial atos da presidência), contribuindo para reforçar as notícias de conflitos e intrigas curiais dos bastidores do Supremo, em detrimento da construção de uma identidade coletiva que fortaleça a instituição.

A influência do discurso midiático na construção da imagem do STF é inegável, visto que o mesmo tem atuado de maneira cada vez mais ativa em assuntos políticos. A cobertura midiática do julgamento da Ação Penal 470 nos mostrou o quanto essa relação é controversa. Enfim, é preciso aprofundar ainda mais a discussão sobre o papel da política e do Judiciário na democracia brasileira, tendo em vista as transformações advindas dos meios de comunicação.

Finalmente, do tema abordado, cabem questionamentos que não puderam ser tratados no presente artigo: $O$ processo da midiatização do Poder Judiciário terá sido diferente ao ocorrido com outros poderes ou instituições politicas? O caso do poder judiciário brasileiro e sua TV justiça, seria um caso fora da curva nos contextos global e regional? São questões que demandam ${ }^{22}$ pesquisas futuras.

22 Agradecemos aos pareceristas anônimos da revista pelas 'provocações', cujo desafio será devidamente aceito como agenda de pesquisas futuras. 


\section{REFERÊNCIAS}

BERGAMASCO, Débora; RECONDO, Felipe. Estadão, São Paulo, 2 ago. 2012. Disponível em: <http://politica.estadao.com.br/noticias/geral,tv-justica-pode-teraudiencia-recorde-com-mensalao,909793>. Acesso em: 15 maio 2015.

BRASIL. Lei no 10.461, de 17 de maio de 2002. Acrescenta alínea ao inciso I do art. 23 da Lei no 8.977, de 6 de janeiro de 1995, que dispõe sobre o Serviço de TV a Cabo, para incluir canal reservado ao Supremo Tribunal Federal. Disponível em: <www. planalto.gov.br/ccivil_03/leis/2002/110461.htm>. Acesso em: 13 dez. 2015.

BRASIL. Supremo Tribunal Federal. Ação Penal 470. 2013. Disponível em: $<$ http://www.stf.jus.br/arquivo/cms/noticianoticiastf/anexo/ap_470_embargos_ infrigentes $>$. Acesso em: 15 jun. 2015.

BRASIL. Supremo Tribunal Federal. AP 470 - Ação Penal. 2007. Disponível em: $<$ http://www.stf.jus.br/portal/processo/verProcessoDetalhe.asp?incidente=11541>. Acesso em: 15 nov. 2015.

BRASIL. Supremo Tribunal Federal. Notícias STF. Disponível em: <http://www.stf. jus.br/portal/cms/listarNoticiaUltima.asp>. Acesso em: 4 dez. 2015.

BUCCI, Eugênio. O estado de Narciso: a comunicação pública a serviço da vaidade particular. São Paulo: Companhia das Letras, 2015.

CARVALHO, Luiz Maklouf. “Data Venia, O Supremo": "o Supremo, quousque tandem?" Piauí, Rio de Janeiro: São Paulo, v. 4, n. 48, p. 34-41, 2010. Disponível em: $<$ http://revistapiaui.estadao.com.br/edicao-48/questoes-juridicas/o-supremoquousque-tandem>. Acesso em: 30 nov. 2015.

DEBORD, Guy. A sociedade do espetáculo. Versão eletrônica produzida para eBooks. São Paulo, 2003. Disponível em: <http://www.ebooksbrasil.org/adobeebook/ socespetaculo.pdf $>$. Acesso em: 10 mar. 2013.

FOUCAULT, Michel. A arqueologia do saber. 7. ed. Tradução de Luiz Baeta Neves. Rio de Janeiro: Forense Universitária, 2004.

GARAPON, Antoine. O juiz e a democracia: o guardião das promessas. Tradução de Maria Luiza de Carvalho. Rio de Janeiro: Revan, 1999.

KOERNER, Andrei. Ativismo Judicial? Jurisprudência constitucional e política no STF pós-88. Novos Estudos, São Paulo, n. 96, p. 69-85, jul. 2013.

LATOUR, Bruno. La fabrique du droit: une ethnographie du conseil d'État. Paris: La Découverte, 2004. 
MANZANO, Gabriel. Suprema Corte Americana é um mundo secreto e a brasileira é um reality-show. O Estado de São Paulo, São Paulo, 19 ago. 2013. Disponível em: $<$ http://politica.estadao.com.br/noticias/geral,suprema-corte-americana-e-ummundo-secreto-e-a-brasileira-e-um-reality-show,1065703>. Acesso em: 14 dez. 2015.

MAUS, Ingeborg. Judiciário como superego da sociedade: o papel da atividade jurisprudencial na "sociedade órfã". Revista Novos Estudos CEBRAP, São Paulo, n. 58, p. 183-202, nov. 2002.

MELLO, Patrícia Perrone Campos. Nos bastidores do Supremo Tribunal Federal. Rio de Janeiro: Forense, 2015.

MENDES, Conrado Hubner; SILVA, Virgílio Afonso. Entre a transparência e o populismo judicial. Folha de São Paulo, São Paulo, 11 maio 2009. Tendências/ Debates, p. 3. Disponível em: <www1.folha.uol.com.br/fsp/opiniao/fz1105200908. htm>. Acesso em: 23 nov. 2015.

MENDONÇA, Ricardo. Os réus do mensalão têm alguma razão', diz jurista guru dos ministros do STF. Folha de São Paulo, São Paulo, 24 nov. 2013. Disponível em: $<$ http://www1.folha.uol.com.br/poder/2013/11/1375636-os-reus-do-mensalao-temalguma-razao-diz-jurista-guru-dos-ministros-do-stf.shtml>. Acesso em: 23 nov. 2015.

NOVELINO, Marcelo. A Influência da Opinião Pública no Comportamento Judicial dos Membros do STF. In: FELLET, André; NOVELINO, Marcelo (Org.). Constitucionalismo e Democracia. Salvador: Juspodivm, 2013. p. 265-328.

OLIVEIRA, Fabiana Luci. O Supremo Tribunal Federal no processo de transição democrática: uma análise de conteúdo dos jornais Folha de S. Paulo e O Estado de S. Paulo. Revista de Sociologia e Política, Curitiba, n. 22, p. 101-118, set. 2004. Disponível em: <http://ojs.c3sl.ufpr.br/ojs/index.php/rsp/article/view/3664>. Acesso em: 24 nov. 2015.

REQUENA, Jesús González. El espectáculo informativo. Madri: Akal, 1998.

RUBIM, Antônio Albino Canelas. Espetáculo, política e mídia. In: ENCONTRO ANUAL DA ASSOCIAÇÃO NACIONAL DE PROGRAMAS DE PÓSGRADUAÇÃO EM COMUNICAÇÃO, 11., 2002, Rio de Janeiro. Anais... Rio de Janeiro, jun. 2002. Disponível em: <http://www.bocc.ubi.pt/pag/rubim-antonioespetaculo-politica.pdf $>$. Acesso em: 15 jul. 2015.

SADEK, Maria Tereza. Magistrados: uma imagem em movimento. Rio de Janeiro: FGV, 2006.

SCHUBERT, Glendon. The judicial mind: the attitudes and ideologies of supreme court justices 1946-1963. Evanston: Northwestern University Press, 1965. 
SCHWARTZENBERG, Roger-Gérard. O estado espetáculo. São Paulo: Difel, 1978.

SILVA, Mariana Ferreira Cardoso. Vinculação de decisões do STF: aspectos normativos, institucionais e culturais. 2014. 99 f. Dissertação (Mestrado em Direito do Estado) - Faculdade de Direito, Universidade de São Paulo, São Paulo. 2014. Disponível em: <http://www.teses.usp.br/teses/disponiveis/2/2134/tde-11022015081452/>. Acesso em: 22 nov. 2015.

THOMPSON, John B. A mídia e a modernidade: uma teoria social da mídia. 9. ed. Petrópolis: Vozes, 2008.

VIEIRA, Oscar Vilhena. Supremocracia. Revista Direito GV, São Paulo, v. 4, n. 2. p. 441-463. 2008. Disponível em: <www.scielo.br/pdf/rdgv/v4n2/a05v4n2.pdf>. Acesso em: 9 dez. 2015. 